This PDF is a simplified version of the original article published in Internet Archaeology. Enlarged images, and interactive features which support this publication can be found in the original version online. All links also go to the online version.

Please cite this as: Gill, A. 2021 Development-led Archaeology and Public Benefit from a Swedish Perspective, Internet Archaeology 57. https://doi.org/10.11141/ia.57.4

\title{
Development-led Archaeology and Public Benefit from a Swedish Perspective
}

\author{
Alexander Gill
}

\section{Summary}

There has been a specific national policy for culture in Sweden since 1974. Since then, the issue of public access to culture has been a central political objective. The ambition to provide the whole population with access to culture includes knowledge about the past. Making sure that the results of development-led archaeology are beneficial for the general public has therefore been an important issue in Sweden for quite some time.

\section{Introduction}

The invitation to the 2020 EAC symposium proposed that development-led archaeology needs to make a strong case for its support by proving that it creates public value in terms of tangible benefits to state, public, developer and archaeologist. The invitation also stated that archaeology should engage in a two-way process with the public to ensure that archaeological work is seen as a socially inclusive legacy. In addition, the invite also asked if archaeologists are ready to cede control over some aspects of their projects in order to facilitate sustainable, meaningful public benefit.

\section{The organisation of development- led archaeology in Sweden}

In order to understand how issues of public benefit and inclusiveness are handled in Sweden, it is necessary to understand how development-led archaeology is organised.

Development-led archaeology is regional and deregulated. The major stakeholders are the County Administrative Boards, the archaeological investigators, the developers, and the National Heritage Board. County Administrative Boards are government-controlled regional authorities. There are 21 in the country and it is their responsibility to decide whether a developer needs to finance an archaeological excavation. They are also responsible for deciding which archaeological investigator gets to carry out the excavation and how much it can cost. If the regulations call for a competitive bidding process it is the County Administrative Board's responsibility to choose the winning bid. When choosing the best bid, they do not necessarily have to select the cheapest option, 
as the scientific quality of the proposed excavation must be a factor in the decision. The archaeological investigators are museums as well as publicly and privately owned businesses. Their role in the system is to carry out the investigations the County Administrative Boards have determined necessary. The developers' role is simply to bankroll the archaeological investigations required by the County Administrative Boards. The Heritage Board has an overall responsibility for ensuring that the system works but isn't directly involved in the day-to-day business going on in the counties.

\section{Two Ways of Benefiting the Public}

Two different approaches to the issue of public benefit within the field of museums, heritage management and development-led archaeology can be identified in Sweden. The two approaches have created tension and disagreement within the heritage sector for the past 20 years. The first way of approaching public benefit can be described as authoritarian. Archaeologists are considered to be scientific experts who investigate the past and pass on their scientific knowledge to the general public in a one-way process. The value archaeology creates for the public is the possibility for them to obtain a scientifically validated awareness of the past. The other approach is more inclusive and open to the public's participation in the creation of knowledge. The ambition here is to establish a two-way process where museum officials, heritage managers and groups from the public influence each other by sharing experiences and perspectives. In this way knowledge about the past becomes more attuned to the ideas and needs expressed by the general public (Svanberg and Hauptman Wahlgren 2007; Burström 2014).

Looking at some of the heritage conventions produced by UNESCO and the Council of Europe during the last few decades, it is possible to identify both approaches. It is even possible to argue for an ideological shift where a more authoritarian doctrine has been replaced by more inclusive principles.

In the World Heritage Convention (1972), experts occupy an important position of authority when identifying monuments, buildings, and sites of outstanding universal value. The general public isn't really included in what can be described as a top-down process. However, in contrast, the considerably more recent European Landscape Convention (2000) actively promotes inclusion and participation from the general public when identifying important landscapes. The same can be said of the Convention for the Safeguarding of the Intangible Cultural Heritage (2003) that ensures the participation of communities and groups and even, if appropriate, individuals, when recognising important intangible heritage. Finally, the Convention on the Value of Cultural Heritage for Society (2005) also promotes inclusiveness by introducing the concept of heritage communities.

The desire to listen to the public expressed in recent conventions is a clear indication of how issues of inclusion, diversity, participation and two-way communication have become increasingly important within the international policies of heritage management. The new approach towards the public has also influenced archaeologists working in museums and within heritage management in Sweden. 


\section{Tension in Museums and Within Heritage Management}

The ambition to transform museums from authoritarian institutions into meeting places for sharing experiences and perspectives has been criticised and debated for the past 20 years. The arguments put forward by both sides of the debate and the way the debate has unfolded have even become an object of research itself (Svensson 2014).

The aspiration to change how museums present the past has created a division within museums. Some employees want museum exhibitions to be centred upon facts based upon expert knowledge. Others want to use museums as instruments to confront different issues in present-day society such as discrimination and xenophobia. Critics have argued that the ambition to transform museums has induced the questioning of archaeologists' and museums' authority and has created the possibility for just about anyone to use history for their own purposes. Politicians in government have consequently been caught up in the debate and have been accused of attempting to use state-funded museums to serve their own political agendas (Wong 2016a; 2016b; Eng 2018).

Critics support their objections by arguing that the long-standing parliamentary approved objective to distribute culture to everybody in society isn't the only aim. Since the inception of cultural policy, there has also been a fundamental objective that the contents of culture, i.e. what is exhibited in museums or played in theatres, needs be free from political control. The notion that cultural institutions need to be independent from political meddling was originally based in John Maynard Keynes principle that the distribution of support to cultural institutions should be carried out at 'arm's length'. The principle was created by Maynard Keynes in response to concerns about state governance of cultural institutions that had risen in the milieu of totalitarian regimes connected to the second world war (Johansson 2017, 174).

\section{Development-led Archaeology and Public Benefit in Sweden}

The schism regarding political influence that has characterised discussions about museums in general and the mediation of archaeological knowledge within museums has, however, not affected contract archaeology. Development-led archaeology has perpetuated an authoritarian, top-down, one-way, relationship with the general public. Archaeologists within development-led archaeology are respected and their expertise and integrity are seldom, if ever, questioned by journalists or otherwise debated. A reason for this state of affairs is probably that the Historic Environment Act requires that the scientific quality of development-led archaeology must be good. This requirement empowers archaeologists at the County Administrative Boards to uphold standards set by the scientific community and not be tempted to prescribe that archaeological investigators need to develop methods adhering to policies of inclusiveness and twoway communication in their tenders. The obligation to uphold good scientific quality within development-led archaeology does in fact mean that archaeologists at the County 
Administrative Boards are protected and kept at arms length from political control concerning the contents and direction of the archaeological investigations they order.

In a recent bill, the Swedish government has pointed out that it expects development-led archaeology to contribute to the advancement and distribution of new knowledge about the past (Regeringen 2017, 150-52). The ambition to discover new things about the past is clearly deemed enough in itself and it is therefore not necessary for development-led archaeology to identify other ways of measuring how it benefits the public, state or developers.

\section{Two Changes}

To increase development-led archaeology's ability to benefit the public, the regulations that make up the system and the interpretation of the regulations have been altered twice during the past 30 years, in 1994 and the then in 2014. Before 1994, developmentled archaeology's only concern was excavating and documenting ancient remains. The intended recipients of excavation reports were universities and museums, where new information about ancient remains was to be studied by researchers and turned into knowledge about the past for the benefit of the greater good. When it became clear that this system wasn't working effectively, the interpretation of the Historic Environment Act was revised. In a research bill, the Government proposed that development-led archaeology needed to do its own research. Documentation of ancient remains wasn't considered to be enough anymore. To make sure that excavation results were useful for the research community it was important that development-led archaeology presented its results within the framework of an advancing research process (Regeringen 1994, 146, 147). It suddenly became possible for County Administrative Boards to make a broader interpretation of the Historic Environment Act's regulations concerning good scientific quality. The County Administrative Boards began to require that developers financed not just the documentation of ancient remains, but also the presentation of the excavation results within a scientific framework aimed at contributing to the advancement of new knowledge. Since then archaeological investigators have produced a vast amount of research, presented in a variety of books, papers, peer-reviewed papers and conferences, benefiting the development of knowledge about prehistory and history in Scandinavia.

The second development of the system came about in 2014 when Parliament altered the Historic Environment Act. The concept of communication was incorporated in the law giving the County Administrative Boards authority to force developers to pay for the communication of excavation results and research results to the general public. This improvement gave development-led archaeology the means to achieve the political objective of distributing knowledge about the past to the general public. Since then there has been a significant increase in guided tours of excavation sites as well as the production of popular science published in books, magazines and websites.

The production of popular science for the benefit of the public has been successful. However, it has also raised questions concerning whether there are groups in society that are excluded from the possibility of receiving development-led archaeology's communications. At the moment the Swedish National Heritage Board is funding a research project aimed at identifying how development-led archaeology can improve its communication with groups in society with different disabilities. The project's objective is primarily to identify methods that will improve access to excavation sites 
(Engström 2017). The National Heritage Board hopes that the project's results will be of use to the County Administrative Boards in the future when they decide if developers need to finance guided tours of excavation sites and how those tours need to be set up.

\section{Conclusion}

Development-led archaeology in Sweden hasn't been affected by changing international heritage policies in the direction of inclusiveness, participation and two-way communication. It also hasn't been asked to prove its value for solving other issues in society, as that would be at odds with the arms-length principle prevalent in Swedish cultural policy. Instead, the growth of development-led archaeology has been focused on creating legal instruments that enable archaeologists to do their own research and to produce meaningful new knowledge about the past as a way of benefiting the general public.

\section{Bibliography}

Burström, M. 2014 'More than a sensitive ear: what to expect of a professional expert' in J. Schofield (ed) Who Needs Experts?: counter-mapping cultural heritage, Farnham:

Ashgate. 101-12.

Eng, S. 2018 'Historien vi ärvde', Populär Arkeologi 4, 16-19.

Engström, E. (ed) 2017 FuTArk: Funktionsvariation, tillgänglighet, Uppdragsarkeologi, Västerås: Stiftelsen Kulturmiljövård.

Johansson, Lars-Anders. 2017 Att dansa efter maktens pipa: Kultur i politikens tjänst, Timbro förlag: Stockholm.

Regeringen 1994, Regeringens proposition 1993/94:177. Utbildning och forskning.

Kvalitet och konkurrenskraft. https://www.riksdagen.se/sv/dokumentlagar/dokument/proposition/utbildning-och-forskning GH03177

Regeringen 2017, Regeringens proposition

2016/17:116. Kulturarvspolitik. https://www.riksdagen.se/sv/dokumentlagar/dokument/proposition/kulturarvspolitik H403116

Svanberg, F. and Hauptman Wahlgren, K. 2007 Publik arkeologi, Lund: Nordic Academic Press.

Svensson, C-J. 2014 Festligt, folkligt, fullsatt? Offentlig debatt om Historiska museets publika verksamhet från Den Svenska Historien till Sveriges Historia, Jönköping: Jönköping University.

Wong, O. 2016a 'Bah Kuhnkes kulturpolitik hotar kulturarvet', Svenska Dagbladet 28 September 2016.

Wong, O. 2016b 'Vem är det som har kolonial blick egentligen?', Svenska Dagbladet 7 July 2016. 
